\title{
OIL PRICE ASYMMETRY, ENERGY USE AND ECONOMIC GROWTH TRANSITION IN NIGERIA
}

\author{
Adedayo Emmanuel Longe', Caleb Olugbenga Soyemi ${ }^{{ }^{2}}$, David Adeiza Agbanujiß, \\ Oladayo Omitogun ${ }^{1}$ and Idowu Jacob Adekomi
}

${ }^{1}$ Centre for Petroleum, Energy Economics and Law, University of Ibadan, Ibadan, Oyo State, Nigeria

${ }^{2}$ Department of Economics, Olabisi Onabanjo University, Ago Iwoye, Ogun State, Nigeria

${ }^{3}$ Energy Economics, Management and Policy, Emerald Energy Institute, Uniport, Nigeria

The study accounts for the structural break effect in the context of Nigeria. According to the findings obtained, the linear Autoregressive Distributed Lag (ARDL) bounds test reveals that the possibility of a long-term co-integrating relationship is inconclusive. When the study further accounts for asymmetry and the structural break period, however, the Nonlinear Autoregressive Distributed Lag (NARDL) bounds test reveals that there is no long-term co-integrating relationship among the variables in Nigeria within the specified period. According to the results of the NARDL test, both the positive and the negative changes in the oil price and energy use have a negative significant impact on economic growth in Nigeria in the short run, whereas the Consumer Price Index (CPI) exerts a positive and significant impact on economic growth in the short run. The Error Correction Model (ECM) result shows that the independent variables can correct about $94 \%$ of the short-run deviation of economic growth from equilibrium in the long run. The study concludes that, irrespective of the changes in the Bonny Light crude oil price, its impact remains the same on the Nigerian economic growth.

Keywords: oil price, consumer price index, energy use, economic growth

JEL Classification: C32, 013, 047

\section{INTRODUCTION}

Oil price asymmetry is a lack of the oil price equality or equivalence. It may also be referred to as the oil price fluctuation. Discussion on the impact of the oil price fluctuations on economic growth remains an

* Correspondence to: C. O. Soyemi, Department of Economics, Olabisi Onabanjo University, Ago-Iwoye, Ogun State, Nigeria; e-mail: caleb.soyemi@oouagoiwoye.edu.ng interesting and attractive topic among researchers in the economies of oil producing countries. It has been argued though that the growth trend of an economy is more influenced by macroeconomic variables, such as inflation, unemployment, trade, the interest rate, savings, and investment, among other variables (Omitogun \& Longe, 2017; Longe, Adelokun \& Omitogun, 2018; Ahmed, Bhutto \& Kalhoro, 2018). There is a strong correlation between the oil price and 
Nigeria's economic growth, given its dependency on oil as its mainstay (Omitogun, Longe \& Muhammad, 2018).

Bonny light oil was discovered for commercial purpose in Nigeria in 1956. It is graded as sweet oil with a low-sulphur environmental impact.

The Nigerian economy has been recording slow growth since the oil price shock experienced in 2014 that led the economy into a recession in 2016, the growth rate being recorded at a range below its Economic Recovery Growth Plan (ERGP) target of 7\% by the year 2020 .

The recent oil war between Saudi Arabia and Russia (the two giant oil producers) and the outbreak of COVID-19, however, have prompted a revision of its expected growth. Initially in January 2020, the International Monetary Fund (IMF) forecast Nigeria's economic growth for 2020 at $2.5 \%$, assuming that the oil sector would continue to recover and the agriculture sector would regain the momentum after a worthy harvest. Due to the continuous decline in the international oil price recently experienced in 2020 and the COVID-19 pandemic, however, the growth rate was revised downwards at $4.3 \%$ for the year 2020 given Nigeria's vulnerability to twin shocks. This exposure is no doubt traced to its large dependency on crude oil revenue and on having a larger amount of imported goods in use for its domestic activities. The Nigerian Bureau of Statistics (NBS), however, reported a $1.92 \%$ contraction in the Nigerian economy for the year 2020 due to the impact of the oil price turbulence and the covid-19 pandemic disruption on economic activities.

Theoretically, changes in the oil price have two effects: first, the demand side effect and second, the supply side effect. When the demand side is concerned, a positive change in the oil price positively adjusts the price of the fossil fuel energy use, which results in an increase in the cost of the transportation of goods and services, which adds to the production cost and increases the final price of goods and services to the end user. Following the demand law, this effect therefore reduces consumer consumption power which is in contraction with an economy's expected growth. From the supply side, an increase in the oil price causes the production cost to increase via the energy consumed in the production process. For example, given the fact that Nigeria is an oil product importing country, positive oil price changes increase the monetary value or the cost of oil products (such as premium motor spirit, dual purpose kerosene, and AGO) as the crude oil importing country would want to cover the cost of buying at a higher price through the sale of refined products. As a result of this, as the price of the oil product used in the production process increases, producers' production capacity is negatively affected given the fact that the monetary value of their current capacity drops via the exchange rate, thus leaving the country's growth transition unfavored. This implies that there is a connection between the oil price fluctuations and the energy consumed and the consumer price index of the Nigerian economy. Negative oil price changes turn around the effect on both the demand side and the supply side.

On the methodological front, different studies have applied different, various methods, such as the Online Linguistic Support (OLS), the ARDL model, the Vector Autoregression (VAR) model, the Vector Error Corection (VECM) method, and the Granger Causality Test, to analyze the impact of the oil price changes on economic growth in Nigeria. Albeit, they all came up with different findings, since some argued the impact was significant (Akinleye \& Ekpo, 2012; Idrisov, Kazakova \& Polbin, 2015; Ebele \& Iorember, 2015; Gummi, Buhari \& Muhammad, 2016; Ogboru, Rivi \& Idisi, 2017) and some argued that the impact was insignificant (Ayadi, 2005; Odularu, 2007; Omitogun et al, 2018), but the findings are based on the differences in the scope, the method and interpretation.

There is no doubt that the Nigerian economy is exposed to both external demand and supply shocks. The question, however, that has remained unanswered is first, how the oil price regimes and some other key variables, such as the consumer price index and the energy use, affect Nigeria's growth transition. Among the studies reviewed to the best of our knowledge, no study has actually captured 
the effect of structural breaks in the Nigerian model specified with the energy use and the consumer price index, either, which may have influenced the outcome of the study and the results. The second question that is to be answered is that to what extent the structural breaks identified through the oil price regimes affect Nigeria's economic growth? These questions are considered as important, and they need to be answered given the fact that they capture both consumer and investor decision-making in the economy towards their respective engagement in the activities that may contribute to the country's economic growth. Accordingly, the research goals of this paper are to investigate whether:

- the oil price regimes, the consumer price index and the energy use affect Nigeria's growth transition or not, and

- the effect of the structural breaks identified through the oil price regimes affect Nigeria's economic growth or not.

Based upon the foregoing, the hypotheses of the study are as follows:

- The oil price regimes, the consumer price index and the energy use have no effect on Nigeria's economic growth.

- The structural breaks identified through the oil price regimes have no effect on Nigeria's economic growth.

These hypothetical propositions are tested using the ARDL model on the time-series data of the variables.

The rest of the study is organized into four sections. Section Two deals with a literature review. Section Three demonstrates the methodology and the data. In Section Four, the results obtained in the study and discussion are given. Section Five contains the summary and the conclusion.

\section{LITERATURE REVIEW}

Theoretically, according to G. Idrisov et al (2015), the impact the oil price exerts in the context of the
Solow growth model can be traced through capital accumulation for a largely oil-dependent nation. This approach was considered by M. Kazakova, S. Sinelnikov-Murylev and P. Kadochnikov (2009); M. Kazakova and S. Sinelnikov-Muryleu (2008) and M. Kazakova (2009). Hypothetically expanding the Solow growth model, G. Idrisov et al (2015) assume that an economy consists of the two sectors: the oil sector and the non-oil sector. They premised their argument on the assumption that the economy is in steady-state economic growth at a rate equal to the addition of the population and productivity growth rates. They further assume an increase in the oil price, which is the income from abroad that can either be consumed or invested. Therefore, an increase in the oil price increases investment funding sources, which positively adds to accumulated capital within the domestic economy and increases physical outputs. This discussion, however, suffers from the impact negative changes in the oil price would have on economic growth through the other macro-economic variables, such as the consumer price index and the energy use in the form of technological development.

Empirically, D. Ven and R. Fouquet (2017) used the structural oil market VAR model to identify supply, aggregate demand and residual shocks to energy prices and estimated their changing influence on the energy prices and the Gross Domestic Product (GDP). Their study identified that supply shock impacts became greater with an increase in coal dependency and declined with partial transition to oil. Transition from exporting coal to importing oil, however, increased the negative impacts of the demand shocks.

In the OECD countries, R. Eyden, M. Difeto, R. Gupta and M. Wohar (2018) used different panel data techniques, such as the Generalised Method of Moment (GMM), the Feasible Generalised Least Squares (FGLS) Random Coefficients (RC), among other methods, to analyze the economic growth reaction to the oil price volatility. The study took a sample of the 17 OECD member countries, and the data sampling was performed for the period between 1870 and 2013. The study findings noted that the oil price volatility had a negative statistically significant impact on the sampled members' economic growth. 
The study further analyzed the heterogeneity effect amongst the countries, and it was noted that the economic growth of the oil producing countries was for the most part affected by the uncertainty of the oil price, especially so Norway and Canada. F. Jawadi and Z. Ftiti (2018) used on/off threshold regression to analyze the asymmetric, nonlinear and time varying oil/GDP relationship with regards to the business cycle phases in Saudi Arabia. In their study, they also tested the diversification policy implemented through the National Transformation Program (Saudi Vision 2030) so as to verify the equity-energy investment possibility of improving the growth status of Saudi Arabia. Their result confirms that the relationship between oil and the Saudi Arabian economy exhibits nonlinearity and the threshold (there is a certain level of volatility in the oil market that will have an impact on the economy) effect as the impact varies per regime, depending on the market status. It was also verified that the diversification route would stimulate the oil benefit effect on the Saudi Arabian economy. P. Wesseh and B. Lin (2018) used the unrestricted Vector Autoregressive (VAR) model to model the upward and downward movements of the oil price and the exchange rate effect on Liberia's economic growth using the data over a span from 1980 to 2015. The findings obtained in the study show that positive changes in the oil price stimulate Liberia's economic growth. The exchange rate depreciation in Liberia causes economic growth to fall, whereas appreciation tends to have no significant impact on the economic growth of the Liberian economy. Lastly, the study noted that a trade balance and consumer prices were positively correlated with economic growth in the economy. The study, however, differentiates itself by concluding that positive changes (increases) in the oil price have a positive impact on the economy of netoil importers. A. Evgenidis (2018) investigated the impact of the oil price shocks in the Euro Area using the threshold VAR model. The findings obtained in the study show that a higher uncertainty of the oil price impedes a greater effect on the output than it is the case when such uncertainty is lower. However, besides the output effect, the study also notes that stock markets respond more negatively to an increase in oil price shocks, whereas, irrespective of the oil price changes, the consumer price is largely affected.

J. Cunado, S. Jo and F. de Gracia (2015) considered the impact of structural oil shocks for the top four oil-importing Asian countries using the Vector Autoregressive (VAR) model. The study identified the three different structural oil shocks depending on sign restrictions: oil supply shocks, oil demand shocks as a result of increased economic activities, and oil-specific demand shocks. The result shows that, depending on their nature, the economic activity and prices purely differently respond to the oil price shocks. Particularly so, the impact of the oil supply shock is limited, while the demand shock driven bythe global economic activity has a significant positive effect in all the four Asian countries. The study further submitted that the policy tools such as interest rates and exchange rates help mitigate the effects of supply shocks in Japan and Korea, but they can be more actively used in curbing demand shocks. With a special focus on the post-2009 Euro Areas effect of the oil price shocks on macroeconomic and financial markets, C. Morana (2017) used the semiparametric dynamic conditional correlation model. The study confirmed that recessionary periods were triggered off by the seasons of the oil price hikes and, in some cases, by the oil price slumps. The post-2009 nature of the oil price significantly contributed to the sluggish growth of the considered areas. Ahmed et al (2018) examined the impact of the oil price shocks in India, Pakistan, Bangladesh, Sri Lanka and Bhutan using the Impulse Response Factor (IRF) and the Forecast Error Variance Decomposition Method (FEVDM). The IRF result shows significant variations among all the macroeconomic variables in response to the exogenous oil price shocks at different time horizons. According to the study, the implication of this reflects in the fact that macroeconomic variables are sensitive to even small oil price shocks and that they have various socioeconomic implications. The FEVDM confirms the fact that there are variations in how economies react to oil price shocks. J. Kouton (2019) examined the asymmetric heterogeneous relationship between the energy use and economic growth in the 19 selected African countries in a span from 1971 to 2014. In the study, the NPARDL model was used, and the asymmetric panel causality test was done for the 
estimates. The empirical results suggested that the relationship between the energy use and economic growth was asymmetric and depended on the phases of the economic cycle.

S. Ghosh and K. Kanjila (2020) investigated the potential impact of promoting non-fossil fuel energy on India's economic growth using a regime based the nonlinear asymmetric framework. The empirical outcomes affirmed the regime-shift and asymmetric co-integrating links of the non-fossil fuel energy use represented by combustible renewables and waste (CREW) and alternative and nuclear energy with the GDP. The study confirmed the fact that the causal links between combustible renewables and waste and the GDP were regime-variant and asymmetric, on the one hand, whereas the dynamism between alternative and nuclear energy and the GDP was proven to be both asymmetric and regime-invariant, on the other.

L. Kilian and R. Vigfusson (2011) tested the estimations made in the existing studies of the impact of the oil price shocks using the VAR model, analyzing the symmetric and asymmetric links between the energy prices and the U.S. economy. Their findings reveal an inaccurate magnitude in either direction. The study noted that the M. Karaki (2017) re-examined real GDP asymmetric response to the oil price declined. The study also tested the symmetry effect following L. Kilian and R. Vigfusson (2011). The findings do not go against L. Kilian and R. Vigfusson (2011). The asymmetric result, however, shows the unstable feedback of the real oil price. The effect, however, vanishes after a robustness check.

A. P. Gbatu, Z. Wang, P. K. Wesseh and I. Y. Tutdel (2017) applied both the asymptotic and bootstrap distribution techniques so as to model the impact that various oil price shocks exert on macroeconomic variables in Liberia. The study noted that the different oil price shocks with different effects and the existence of asymmetries in the oil price could be explained by Liberia's lack of structured financial markets and its tight monetary policy controls and that a rise in the oil price shocks favored Liberia's economic growth. In Malaysia, H. Ahmed and M Wadud (2011) used the structural VAR model to analyze the data over a span from 1986 to 2009. The study found the existence of the dampening effect of the oil price shocks on the macroeconomic variables in Malaysia's economy. In reaction to such oil price uncertainties, however, the study also noted that the Malaysian economy adopted expansionary monetary policies to curb the said effect.

I. Raheem (2017) tested the asymmetric response of the trade channels of different countries to oil price shocks using the Nonlinear Auto-Regressive Distributed Lag (NARDL) technique and monthly datasets for the period from 01/1992 to 06/2016. The selected countries are China and Germany (hightrading countries), U.S. and India (oil-importing countries) and Russia and Canada (oil-exporting countries). The findings obtained in the study show that there is a long-term asymmetric effect of oil price shocks on the export component of the high-trading economies (namely China and Germany), a short-term impact on the imports of the oil-importing countries (namely the U.S. and India), and a long-term impact on the import of the oil-exporting countries (namely Russia and Canada). It was, however, concluded that the result might change in relation to changes in the data frequency. U. Bala and L. Chin (2018) verified the asymmetric link between the oil price and inflation in the African OPEC member countries (namely Algeria, Angola, Libya and Nigeria) using ARDL dynamic panels to estimate the short- and long-term links. It was observed that both the positive changes and the negative changes in the oil price had a positive impact on inflation in those economies, which were more significant whenever there was a negative change in the oil price.

In Nigeria, O. Ayadi (2005) examined the development of the Nigerian economy via industrial production as it was affected by the oil price fluctuations using the VAR model for the data spanning from 1980 through to 2004. The analysis revealed that the oil price had exerted an impact on the country's industrial production through the exchange rate volatility, but the same was not statistically significant. According to the findings of the study, a conclusion was made that the increase in the oil price in Nigeria did not translate to an increase in industrial production. 
Omitogun et al (2018) used the data over a span from 1981 to 2016, adopting the ARDL model to investigate the impact of the oil price and revenue variations on economic growth. The study noted that, the oil price, the consumer price index, and the exchange rate positively related with economic growth in the long run, whereas oil revenue simultaneously negatively influenced Nigeria's economic growth. In the short run, the oil price and revenue exert a positive impact on economic growth, whereas the consumer price index and the exchange rate have a negative impact on Nigeria's economic growth. Longe et al (2018) checked the long- and short-term link between the oil price fluctuations and the Nigerian currentaccount balances using the ARDL model with the data spanning from 1977 to 2015. In the short run, the study reveals that the oil price has an impact on the current account balances, and that the impact is positive and insignificant, whereas in the long run, the same is negative and significant. I. Ogboru et al (2017) adopted the Vector Error Correction Model (VECM) to analyze the impact of changes in crude oil prices on Nigeria's economic growth. The study findings reveal that all the variables contributed to the convergence of economic growth to a long-term equilibrium and that there is a positive unidirectional relationship between changes in crude oil prices and economic growth. U. Gummi et al (2016) examine the causal link between the oil price and economic growth in Nigeria. The result reveals that there is a unidirectional causal link between the oil price and economic growth. Based on the OLS results, G. Odularu (2007) argued that crude oil consumption in the Nigerian economy was insignificant to its growth, but the export services were found to be significant and to exert a positive impact on its economic growth. S. Akinleye and S. Ekpo (2012) tested the truism of the existence of the Dutch disease syndrome in the short run and in the long run in the context of Nigeria. Their findings show that shocks in oil revenue disrupt growth and hamper the price level in the short run.

According to the empirical studies presented in this literature review, discussion on the impact of the oil price on economic growth remains inconclusive given its volatility nature. The dynamic findings and the conclusions emanated from the different approaches applied and the different goals set in the foregoing studies. However, following the argument made by O. Ayadi (2005) that the oil price has an impact on economic growth, but that impact is not direct, this study focusses on extending this argument by considering the various means through which growth transition in Nigeria is affected through the oil price volatility, the average price of goods and services, and the energy use.

\section{METHODOLOGY AND DATA}

To expand the G. Idrisov et al (2015) theoretical discussion, the study follows the O. Ayadi (2005) and D. Ven and R. Fouquet (2017) models.

First, the model is specified in its linear-linear form as:

$$
Y=f(B L, C P I, E)
$$

where:

$Y$ is the GDP, the economic growth proxy, $B L$ is the Bonny Light crude oil price, $C P I$ is the consumer price index, and $E$ is energy consumption.

The model is respecified in an econometric log-log form as:

$$
\operatorname{In} Y=\alpha_{0}+\beta_{1} \operatorname{In} B L_{t}+\beta_{2} \operatorname{In} C P I_{t}+\beta 3 \operatorname{In} E_{t}+\mu_{t}
$$

where:

InY, InBL, InCPI and InE imply the log form of the GDP, the log form of the Bonny Light crude oil price, the log form of the Consumer Price Index and the log form of energy consumption, respectively, $\alpha_{0}$ is the intercept of the model, $\beta_{1}-\beta_{3}$ are the coefficients of the estimated parameters, $t$ is the time and $\mu$ is the error term.

According to Equation 2, the short- and long-term oil price NARDL model, the CPI, the energy use and economic growth are stated as follows: 


$$
\begin{aligned}
\Delta \operatorname{In} Y_{t} & =\vartheta_{0}+\sum_{q=1}^{n} \rho_{1} \Delta \operatorname{In} Y_{t-k}+\sum_{q=1}^{n} \rho_{2} \Delta \operatorname{In} B L_{t}^{+} \\
& +\sum_{q=1}^{n} \rho_{3} \Delta \operatorname{In} B L_{t}^{-}+\sum_{q=1}^{n} \rho_{4} \Delta \operatorname{InCPI} I_{t-k} \\
& +\sum_{q=1}^{n} \rho_{5} \Delta \operatorname{In} E_{t-k}+\beta_{1} \operatorname{In} Y_{t-1}+\beta_{2} \operatorname{In} B L_{t}^{+} \\
& +\beta_{3} \operatorname{InBL}_{t}^{-}+\beta_{4} \operatorname{InCPI} I_{t}+\beta_{5} \operatorname{In} E_{t} \\
& +\delta e c m_{t-1}+\mu_{t}
\end{aligned}
$$

In order to consider the structural break effect, the NARDL model in Equation 3 is respecified as follows:

$$
\begin{aligned}
\Delta \operatorname{In} Y_{t} & =\vartheta_{0}+\sum_{q=1}^{n} \rho_{1} \Delta \operatorname{In} Y_{t-k}+\sum_{q=1}^{n} \rho_{2} \Delta \operatorname{In} B L_{t}^{+} \\
& +\sum_{q=1}^{n} \rho_{3} \Delta \operatorname{In} B L_{t}^{-}+\sum_{q=1}^{n} \rho_{4} \Delta \operatorname{InCPI} I_{t-k} \\
& +\sum_{q=1}^{n} \rho_{5} \Delta \operatorname{In} E_{t-k}+\beta_{1} \operatorname{In} Y_{t-1}+\beta_{2} \operatorname{InB} L_{t}^{+} \\
& +\beta_{3} \operatorname{InBL}_{t}^{-}+\beta_{4} \operatorname{InCPI} I_{t}+\beta_{5} \operatorname{In} E_{t} \\
& +\operatorname{\delta ecm}_{t-1}+\sum_{r=1}^{s} B_{r} \operatorname{Dummy}_{r t}+\mu_{t}
\end{aligned}
$$

According to Equations 3 and $4, \Delta$ denotes the changes in the variables in the short run, $n$ is the optimal lag length, $\mu_{t}$ is the error term at a time. The parameters $\rho(i=1,2,3,4,5)$ are the corresponding long-term multiplier, and the parameters $\beta=(1,2,3,4$, 5) are the short-turn dynamism of the NARDL model. $\delta \mathrm{ecm}$ is the parameter estimate of the error correction model. Dummy is the dummy variable for the break defined as Dummy $y_{r t}=1$ for $t>T_{B^{\prime}}$ otherwise Dummy $=0 . t$ represents the time; $T_{B}$ is the structural break date, where $r=1,2,3, \ldots, k$ and $B$ is the coefficient of the break dummy.

In the study, the annual time series data on the Gross Domestic Product (per capita at the current LCU), the Consumer Price Index (CPI) and Energy Consumption Per capita (oil equivalent per capita) from the World Development Indicators (WDI) (2019) and the Oil Prices (WTI and Brent) from the BP Statistics
(2019) and the Bonny Light (BL) crude oil price from the Energy Information Administration - EIA (2019) were used. The data span from 1978 to 2016 . The study limits its scope due to the availability of the data on some variables, such as energy consumption per capita.

\section{RESULTS AND DISCUSSION}

\section{Descriptive statistics}

In the study, a behavioral analysis of the variables used in the study was carried out using the descriptive statistics technique. The results presented in Table 1 show that the variables (the GDP, the BL, the CPI and E) change within the studied period by $4.23 \%$, $1.54 \%, 1.037 \%$, and $2.85 \%$ on average, respectively. The variables are well-behaved as their mean values fall within the maximum and the minimum values. The resulting standard deviation shows that the GDP (with the value $1.05 \%$ ) is the variable that is the most volatile to shocks amongst the variables.

Table 1 The results of the descriptive statistics

\begin{tabular}{l|ccccc}
\hline Variables & Obs. & Mean & Maximum & Minimum & $\begin{array}{c}\text { Std. } \\
\text { Dev. }\end{array}$ \\
\hline InGDP & 39 & 4.226 & 5.742 & 2.716 & 1.048 \\
$\operatorname{InBL}$ & 39 & 1.536 & 2.071 & 1.134 & 0.288 \\
$\operatorname{InCPI}$ & 39 & 1.037 & 2.265 & -0.478 & 0.926 \\
$\ln E$ & 39 & 2.852 & 2.902 & 2.810 & 0.023 \\
\hline
\end{tabular}

Source: Authors

\section{Correlation}

According to the obtained result accounted for in Table 2 , it is possible to notice that there is a strong positive significant linear correlation between the independent variables and the GDP, which on its part implies that changes in these variables are more likely to have a significant impact on the dependent variable (GDP). 
Table 2 The correlation results

\begin{tabular}{l|cccc}
\hline Variables & $\operatorname{InGDP}$ & $\operatorname{InBL}$ & $\operatorname{InCPI}$ & $\operatorname{InE}$ \\
\hline $\operatorname{InGDP}$ & 1 & & & \\
& --- & & & \\
$\operatorname{InBL}$ & 0.680 & 1 & & \\
& $0.000^{*}$ & --- & & \\
$\operatorname{InCPI}$ & 0.990 & 0.594 & 1 & \\
& $0.000^{*}$ & $0.000^{*}$ & --- & \\
$\operatorname{InE}$ & 0.872 & 0.804 & 0.837 & 1 \\
& $0.000^{*}$ & $0.000^{*}$ & $0.000^{*}$ & ---- \\
\hline
\end{tabular}

$*, * *, * * *$ implies a significance level at $1 \%, 5 \%$ and $10 \%$, respectively.

Source: Authors

\section{The unit root test}

The unit root test verifies the long-term mean reverting the possibility of the variable and showing whether there is (or there is not) a stationarity problem amongst the variables. This study adopts the Augmented Dickey Fuller (ADF) test (1979) and the Phillip-Perron (PP) test in order to perform a robust stationarity check amongst the variables. Although the two tests assume that no structural breaks are found in the data used over the studied period, they otherwise report the non-stationarity of the variables in the case of such a structural break. According to P. C. B. Phillip and P. Perron (1988), however, the PP unit root test differs from the ADF test mainly in how the errors of serial correlation and heteroskedasticity among the variables are dealt with. P. C. B. Phillip and P. Perron (1988) noted that the ADF tests used parametric autoregression to approximate the ARMA structure of the errors in the test regression, but the PP tests ignored any serial correlation in the test regression. Therefore, considering a high volatility in the crude oil price and its dynamic impact on growth in Nigeria, it is important to affirm the existence of structural breaks and the need for testing them in the study. According to the results presented in Table 3, it was observed that all the variables were stationary after the first difference for both the ADF and the PP tests, only for the CPI that proved to be non-stationary at the level and the first difference considering the PP.
Table 3 The unit root test results

\begin{tabular}{|c|c|c|c|c|c|}
\hline \multirow[b]{2}{*}{ Variables } & \multicolumn{2}{|r|}{ ADF } & \multicolumn{2}{|c|}{ PP } & \multirow[b]{2}{*}{$\begin{array}{l}\text { Order of } \\
\text { Integration }\end{array}$} \\
\hline & Level & $\begin{array}{c}\text { First } \\
\text { Difference }\end{array}$ & Level & $\begin{array}{c}\text { First } \\
\text { Difference }\end{array}$ & \\
\hline InGDP & -1.928 & $-5.360 *$ & -2.105 & $-5.360 *$ & $\mathrm{I}(1)$ \\
\hline $\operatorname{In} E$ & -3.137 & $-4.962^{*}$ & -2.564 & $-4.853^{*}$ & $\mathrm{I}(1)$ \\
\hline $\operatorname{InBL}$ & -1.609 & $-5.427^{*}$ & -1.790 & $-5.427 *$ & $\mathrm{I}(1)$ \\
\hline $\operatorname{InCPI}$ & -0.862 & $-3.756 * *$ & -0.804 & -2.878 & $\mathrm{I}(1)$ \\
\hline CV $1 \%$ & -4.219 & -4.227 & & & \\
\hline $5 \%$ & -3.533 & -3.537 & & & \\
\hline $10 \%$ & -3.198 & -3.200 & & & \\
\hline
\end{tabular}

$*, * *, * * *$ implies a significance level at $1 \%, 5 \%$ and $10 \%$, respectively.

Source: Authors

\section{The ARDL bounds test}

The ARDL bounds test results confirm (Table 4) the fact that the existence of a long-term co-integrating relationship amongst the variables is inconclusive as the F-statistics value falls in between the lower and the upper bounds values, which, therefore, implies that reporting the long-term result for this model is inconclusive (i.e. the same may or may not be reported).

Table 4 The ARDL bounds test results

\begin{tabular}{l|cc}
\hline Test Statistic & Value & $\mathrm{k}$ \\
F-statistic & 4.274042 & 3 \\
Critical Value Bounds & & \\
Significance & Io Bound & I1 Bound \\
$10 \%$ & 3.47 & 4.45 \\
$5 \%$ & 4.01 & 5.07 \\
$1 \%$ & 5.17 & 6.36 \\
\hline
\end{tabular}

$*, * *, * * *$ implies a significance level at $1 \%, 5 \%$ and $10 \%$, respectively.

Source: Authors 


\section{The structural break test}

The Bai-Perron test is used to verify the significant break period which may have affected economic growth the most within the studied period. The structural break analysis of the result shows a break period of 2010 (Table 5), which marks the period in which the oil price was just recovering from the shocks experienced in the year 2008.

Table 5 The structural break test result

\begin{tabular}{l|c|c}
\hline Country & Break Period & Break Range \\
\hline Nigeria & 2010 & $2010-2016$ \\
\hline
\end{tabular}

Source: Authors

\section{The NARDL estimates with breaks}

The NARDL results show that the identified break has a significant impact in the model and that the same is positive in explaining the phenomenon (Table 6). The positive and negative changes in the oil price in the short run negatively and significantly influence the growth of the Nigerian economy. As the Bonny Light oil price changes both positively and negatively, the grow th possibilities are reduced by approximately $33 \%$ and $30 \%$, respectively, in the short run, which is implicative of the fact that Nigeria's economic growth has negatively been exposed to the shocks in the oil price since the discovery of the oil that has diverted the Nigerian economic system from an agriculturebased system to an oil-based economy with no hope of enjoying the benefits of the income from oil in the long run, given the fact that no long-term impact can be reported. The consumer price index has a positive significant impact on growth in Nigeria, which implies the fact that a $75 \%$ increase in Nigerian economic growth is recorded as the average price of all goods and services in Nigeria changes. The result also validates the general supply law, which states that producers are willing to sell more at higher prices because of the profit involved in the scenario.

Table 6 The NARDL estimation results

\begin{tabular}{ll|llll}
\hline & Variable & Coefficient & Std. Error & t-Statistic & Prob. \\
\hline SIC Selected Model: ARDL(2, 3, 0, 4) & $\Delta B L_{t-1}^{+}$ & 0.303 & 0.119 & 2.558 & $0.020^{* *}$ \\
& $\Delta B L_{t-2}^{+}$ & -0.325 & 0.098 & -3.322 & $0.004^{*}$ \\
& $\Delta B L_{t-1}^{-}$ & 0.123 & 0.125 & 0.982 & 0.339 \\
& $\Delta B L_{t-2}^{-}$ & -0.087 & 0.155 & -0.563 & 0.580 \\
& $\Delta B L_{t-3}^{-}$ & -0.297 & 0.130 & -2.283 & $0.035^{* *}$ \\
& $\Delta I n C P I_{t-1}$ & 0.753 & 0.077 & 9.740 & $0.000^{*}$ \\
& $\Delta I n E_{t-1}$ & 3.176 & 1.033 & 3.073 & $0.007^{*}$ \\
& $\Delta I n E_{t-2}$ & -0.417 & 1.203 & -0.347 & 0.733 \\
& $\Delta I n E_{t-3}$ & -0.478 & 1.214 & -0.394 & 0.698 \\
& $\Delta I n E_{t-4}$ & -2.223 & 0.905 & -2.456 & $0.025^{* *}$ \\
NARDL with breaks Bounds Test & $\Delta B 1_{t-1}$ & 0.196 & 0.038 & 5.155 & $0.000^{*}$ \\
Breusch-Godfrey Serial Correlation LM Test: & $E C M_{t-1}$ & -0.944 & 0.109 & -8.624 & $0.000^{*}$ \\
Heteroskedasticity Test: ARCH & & 2.874 & & & \\
Ramsey RESET Test & & 0.802 & Prob. F(2,16) & & 0.197 \\
\hline
\end{tabular}

$*, * *, * * *$ implies a significance level at $1 \%, 5 \%$ and $10 \%$, respectively.

Source: Authors 
As there is willingness to sell more, the output of the economy spikes, which therefore contributes to the general economic growth of the economy as a whole. Energy consumption has a negative significant impact on economic growth in the Nigerian economy, which implies that percentage change in energy consumption brings about $2.22 \%$ declines in Nigerian economic growth. Looking at the nature of the Nigerian power sector, the oil-related energy sources such as fossil fuel products are the common alternative energy consumed by both households and investors. Given the cost attached to this source, economic growth is affected as it withdraws a part of the profit or income of those involved in said consumption.

The error correction model results are correct with a negative sign and significant, and they show a very strong capability of the independent variables correcting about $94 \%$ of the deviation of Nigerian economic growth from equilibrium in the short run back to equilibrium in the long run. Therefore, if the variables are trended in the right direction, there is a high possibility that the growth plan in Nigeria will positively benefit from the independent variables.

\section{The VAR model}

The stationarity status of the variables qualified the study to adopt the VAR model in order to analyze the growth response to the changes in the independent variables (both positive and negative changes in the Bonny Light crude oil price, the consumer price index and energy consumption). The study adopted the Generalized Impulse Response Function (GIRF) in order to analyze the phenomenon. The VAR model is specified in the following manner:

$Y_{t}=A_{1} y_{t-1}+A_{2} y_{t-2}+\ldots+A_{\mathrm{e}} y_{t-\mathrm{e}}+\mu_{t} \quad t=1,2, \ldots, \mathrm{T}$

where:

$A_{1}, A_{2}, A_{\rho}$ and $y_{t-1}, y_{t-2}, y_{t-3}$ are the parameter matrices, $\rho$ is the optimal lag length determined by SIC,

$\mu_{t}$ is the common vector errors and

$t$ is the time range.

According to the results, the impulse response function lies within the lines (i.e. at a 95\% confidence interval). The growth response to the positive changes in the oil price was positive in the early period, but the same declined to a steady state point in the $2^{\text {nd }}$ period, and negatively responded to the changes throughout the periods. It was also noticed that growth had the same response to the negative changes in the Bonny Light crude oil price and energy consumption throughout the periods. Growth was positively influenced by the shocks in the average price of all goods and services in the economy throughout the periods. Those results confirmed the ARDL estimate findings as the positive and negative changes in the Bonny Light crude oil price and energy consumption had a negative impact on growth in the economy and positively responded to the consumer price index (Figure 1).

From the results, it can be deduced that Nigerian economic growth remains below the expected growth despite the different crude oil price regimes (neither positive nor negative), which is so because of Nigeria's large dependency on crude oil as a source of funding the country's development in the other economic sectors. Much of surplus generated when the crude oil price positively changes is used to finance subsidy and insurgencies, and sometimes is mismanaged. Therefore, following the economic development level and the power supply condition, oil-related energy consumption is the best option considered by many investors, which as a result negatively contributes to the economic growth of the economy through their emissions conflicting with the sustainable economic growth plan. The findings also reveal negative changes in the crude oil price have not reached level at which a subsidy can be absolutely eliminated as the oil-related-energy cost of landing (e.g. PMS) is greater than its ceiled price. Given the recent oil price war between Saudi Arabia and Russia (the two giant oil producers) and the COVID-19 pandemic (causing both a demand shock and a supply shock), the oil price crash caused the complete removal of a subsidy as petrol was sold within the range N123.5-N125.00 per liter against its landing cost of N121.54 as at $6^{\text {th }}$ of March 2020. Therefore, Nigeria should save more if it did not largely depend on crude oil and if it diverted the subsidy funds towards the other strategic sectors of the economy. The CPI positive significant impact 

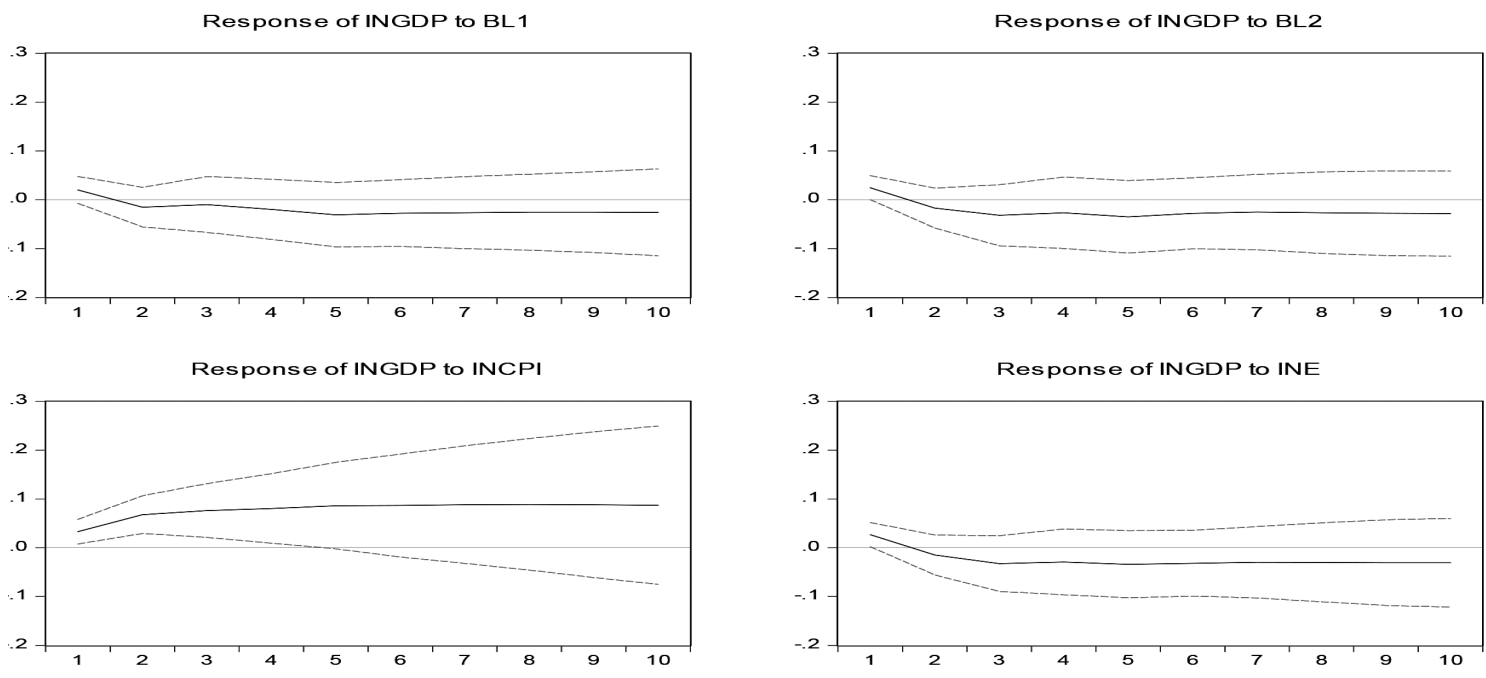

Figure 1 Response generalized 1 S.D. inovations +/- 2 S.E.

Source: Authors

on economic growth transition evidenced that the activities were propelled at high prices in the economy. The study findings also negated G. Idrisov et al (2015) that positive changes in the oil price exert a negative impact on economic growth in the context of Nigeria, which on its part accounts for the fact that the assumption by G. Idrisov et al (2015) is countryspecific and does not represent a holistic view of the expected impact of positive changes in the crude oil price.

\section{CONCLUSION}

The studies extant in the literature have verified the connection between the oil price and economic growth, inflation and economic growth, and energy consumption and economic growth. This study deviates from the existing studies in that it considers the consumer price index, energy consumption and negative and positive changes in the Bonny Light crude oil price using the indigenous price since it is at this price that Nigeria generates crude oil revenue. The study adopts the NARDL and the VAR models in order to analyze the used time series data.
According to the findings, there is no long-term cointegrating relationship amongst the variables that leads us to conclude that there is no reporting of the long-term results. The NARDL estimates show that, in the short run, both positive and negative changes in the Bonny Light crude oil price have a negative significant impact on economic growth in Nigeria, the consumer price index has a positive significant impact on economic growth, whereas energy consumption has a negative significant impact on economic growth. In the long run, these variables correct about 95\% of economic growth deviations from equilibrium in the short run, which has been verified herein. The GIRF confirms that the economic growth response to energy consumption and to negative and positive changes in the Bonny Light crude oil price are the same throughout the periods, whereas its response is positive to the consumer price index throughout the periods specified in the study.

According to the findings of study, neither positive nor negative changes in the Bonny Light crude oil price obviously favor Nigeria's economic growth, the consumption of oil-related energy likewise. Therefore, this confirms the fact that the economy needs to look beyond the oil sector in sustaining 
its economic growth. There is the need to adopt a strategic investment policy towards diverting the little that can be saved from the oil sector to the other sectors. The adoption of this strategy will gradually make it possible for the economy to stop making negative responses to the oil price shocks.

This study is limited in terms of the scope and the data used in it. It can be extended to oil-dependent developing countries in order to robustly check if the facts presented herein also hold for the other related countries.

\section{REFERENCES}

Ahmed, H., \& Wadud, M. (2011). Role of oil price shocks on macroeconomic activities: An SVAR approach to the Malaysian economy and monetary responses. Energy Policy, 39(12), 8062-8069. doi:10.1016/j.enpol.2011.09.067

Ahmed, K., Bhutto, N., \& Kalhoro, M. (2018). Decomposing the links between oil price shocks and macroeconomic indicators: Evidence from SAARC region. Resources Policy, 61(C), 423-432. doi.org/10.1016/j.resourpol.2018.03.001

Akinleye, S., \& Ekpo, S. (2012). Oil price shocks and macroeconomic performance in Nigeria. Economía Mexicana, 22(4), 565-624.

Ayadi, O. (2005). Oil price fluctuations and the Nigerian economy. OPEC Review, 29(3), 199-217. doi:10.1111/j.02770180.2005.00151.x

Bala, U., \& Chin, L. (2018). Asymmetric impacts of oil price on inflation: An empirical study of African OPEC member countries. Energies, 11(11), 1-21. doi:10.3390/en11113017

Cunado, J., Jo, S., \& de Gracia, F. (2015). Macroeconomic impacts of oil price shocks in Asian economies. Energy Policy, 86(C), 867-879. doi.org/10.1016/j.enpol.2015.05.004

Dickey, D., \& Fuller, W. (1979). Distribution of the estimators for autoregressive time series with a unit root. Journal of the American Statistical Association, 74(366), 427-431. doi.org/10.2307/2286348

Evgenidis, A. (2018). Do all oil price shocks have the same impact? Evidence from the euro area. Finance Research Letters, 26, 150-155. doi.org/10.1016/j.frl.2017.12.013
Eyden, R., Difeto, M., Gupta, R., \& Wohar, M. (2019). Oil price volatility and economic growth: Evidence from advanced economies using more than a century's data. Applied Energy, 233, 612-621. doi.org/10.1016/j.apenergy.2018.10.049

Gbatu, A. P., Wang, Z., Wesseh, P. K., \& Tutdel, I. Y. (2017). The impacts of oil price shocks on small oil-importing economies: Time series evidence for Liberia. Energy, 139(C), 975-990. doi:10.1016/j.energy.2017.08.047

Ghosh, S., \& Kanjilal, K. (2020). Non-fossil fuel energy usage and economic growth in India: A study of non-linear cointegration, asymmetry and causality. Journal of Cleaner Production, 273, doi.org/10.1016/j.jclepro.2020.123032

Gummi, U., Buhari, A., \& Muhammad, A. (2016). Oil price fluctuations and economic growth in Nigeria (Evidence From Granger Causality Test). Australasian Journal of Social Science, 3(1), 1-16. doi:10.3923/aujss.2017.1.16

Idrisov, G., Kazakova, M., \& Polbin, A. (2015). A theoretical interpretation of the oil prices impact on economic growth in contemporary Russia. Russian Journal of Economics, 1(3), 257-272. doi.org/10.1016/j.ruje.2015.12.004

Jawadi, F., \& Ftiti, Z. (2018). Oil price collapse and challenges to economic transformation of Saudi Arabia: A time-series analysis. Energy Economics, 80(C), 1-19. doi.org/10.1016/j. eneco.2018.12.003

Karaki, M. (2017). Nonlinearities in the response of real GDP to oil price shocks. Economics Letter, 161(C), 146-148. doi.org/10.1016/j.econlet.2017.09.034

Kazakova, M. (2009). The impact of the oil and gas sector on Russia's economic performance and in the global practice. Rossiyskiy Vneshneekonomicheskiy Vestnik, 8, 66-72.

Kazakova, M., \& Sinelnikov-Muryleu, S. (2008). The environment of the global energy market and Russian economy growth rates. Ekonomicheskaya Politika, 5, 118-135.

Kazakova, M., Sinelnikov-Murylev, S., \& Kadochnikov, P. (2009). Analysis of Structural and Business Component of the Tax Burden in Russian Economy. Moscow, RU: IET Research Paper No. 129 .

Kilian, L., \& Vigfusson, R. (2011). Are the responses of the U.S. Economy asymmetric in energy price increases and decreases? Quantitative Economics, 2(3), 419-453. doi.org/10.3982/QE99 
Kouton, J. (2019). The asymmetric linkage between energy use and economic growth in selected African countries: Evidence from a nonlinear panel autoregressive distributed lag model. Energy Economics, 83, 475-490. doi.org/10.1016/j. eneco.2019.08.006

Longe, A., Adelokun, O., \& Omitogun, O. (2018). The current account and oil price fluctuations nexus in Nigeria. Journal of Competitiveness, 10(2), 118-131. doi:10.7441/joc.2018.02.08

Morana, C. (2017). Macroeconomic and financial effects of oil price shocks: Evidence for the euro area. Economic Modelling, 64(C), 82-96. doi.org/10.1016/j.econmod.2017.03.016

Odularu, G. (2007). Crude oil and the Nigerian economic performance. Oil and Gas Business, 1-29.

Ogboru, I., Rivi, M., \& Idisi, P. (2017). The impact of changes in crude oil prices on economic growth in Nigeria: 1986-2015. Journal of Economics and Sustainable Development, 8(12), 78-89.

Omitogun, O., \& Longe, A. (2017). Unemployment and economic growth in Nigeria in the 21st century: VAR approach. OEconomica, 13(5), 155-168.
Omitogun, O., Longe, A., \& Muhammad, S. (2018). The impact of oil price and revenue variations on economic growth in Nigeria. OPEC Energy Review, 42(4), 387-402. doi.org/10.1111/ opec.12139

Phillips, P. C. B., \& Perron, P. (1988). Testing for unit roots in time series regression, Biometrika, 75(2), 335-346. doi.org/10.2307/2336182

Raheem, I. (2017). Asymmetry and break effects of oil price -macroeconomic fundamentals dynamics: The trade effect channel. The Journal of Economic Asymmetries, 16, 12-25. doi.org/10.1016/j.jeca.2017.04.002

Ven, D., \& Fouquet, R. (2017). Historical energy price shocks and their changing effects on the economy. Energy Economics, 62, 204-216. doi.org/10.1016/j.eneco.2016.12.009

Wesseh, P., \& Lin, B. (2018). Exchange rate fluctuations, oil price shocks and economic growth in a small net importing economy. Energy, 150(C), 402-407. doi:10.1016/j. energy.2018.03.054

\section{Received on $30^{\text {th }}$ November 2020, after revision, accepted for publication on $12^{\text {th }}$ July 2021 \\ Published online on $2^{\text {nd }}$ August 2021}

Adedayo Emmanuel Longe holds B.Sc. in Economics from Olabisi Onabanjo University and a Master in Energy Economics from the Centre for Petroleum, Energy Economics and Law, University of Ibadan.

Caleb Olugbenga Soyemi is a graduate assistant at the Department of Economics, Olabisi Onabanjo University. He earned First Class Honors degree in Economics from Olabisi Onabanjo University. He is currently studying for a master's degree in Economics at the same University.

David Adeiza Agbanuji graduated from the Ahmadu Bello University, Zaria with a B.Eng. in Electrical Engineering and master's degree in Energy Economics from the Emerald Energy Institute, University of Port Harcourt. 
Oladayo Ayokunle Omitogun is a lecturer at the Department of Mineral and Petroleum Engineering, Yaba College of Technology. He received B.Sc. in Geology from Olabisi Onabanjo University and Master in Energy Economics from the Centre for Petroleum, Energy Economics and Law, University of Ibadan.

Jacob Idowu Adekomi earned his first degree in Economics from Olabisi Onabanjo University.

\title{
ASIMETRIJA U CENI NAFTE, KORIŠĆENJE ENERGIJE I TRANZICIJA EKONOMSKOG RASTA U NIGERIJI
}

\author{
Adedayo Emmanuel Longe', Caleb Olugbenga Soyemi², David Adeiza Agbanujiß, \\ Oladayo Omitogun ${ }^{1}$ and Idowu Jacob Adekomi²
}

${ }^{1}$ Centre for Petroleum, Energy Economics and Law, University of Ibadan, Ibadan, Oyo State, Nigeria

${ }^{2}$ Department of Economics, Olabisi Onabanjo University, Ago Iwoye, Ogun State, Nigeria

${ }^{3}$ Energy Economics, Management and Policy, Emerald Energy Institute, Uniport, Nigeria

Ova studija se bavi izučavanjem efekta strukturnih poremećaja u kontekstu Nigerije. Na osnovu nalaza studije, linearni test granica autoregresivnih distribuiranih docnji (ARDL test) upućuje na zaključak da ne postoji realna mogućnost za uspostavljanje dugoročnog odnosa kointegracije. Međutim, kada studija uzme u obzir asimetriju i period strukturnog prekida, test granica nelinearnih autoregresivnih distributivnih docnji (NARDL test) otkriva da, u navedenom periodu, ne postoji dugoročna kointegraciona veza između promenljivih u Nigeriji. Rezultati do kojih se došlo primenom NARDL testa ukazuju na činjenicu da i pozitivne i negativne promene u ceni nafte i korišćenju energije kratkoročno negativno značajno utiču na ekonomski rast u Nigeriji. S druge strane, indeks potrošačkih cena (CPI) pozitivno i značajno kratkoročno utiče na ekonomski rast. Rezultat dobijen primenom modela korekcije greške (ECM model) ukazuje na to da nezavisne promenljive mogu dugoročno da koriguju oko $94 \%$ kratkoročnog odstupanja ekonomskog rasta od ravnotežnog stanja. U studiji se zaključuje da, bez obzira na promene u ceni Bonny Light sirove nafte, ona i dalje podjednako utiče na ekonomski rast Nigerije.

Ključne reči: cena nafte, indeks potrošačkih cena, korišćenje energije, ekonomski rast

JEL Classification:C32, 013, 047 